\title{
The Potential for Extracting Heat Energy from Waste Water: A Strategic Approach
}

\author{
Jürgen Knies \\ iro GmbH Oldenburg, Germany · knies@iro-online.de \\ Full paper double blind review
}

\begin{abstract}
Extracting heat energy from wastewater can be one component of a community's overall strategy towards reducing both primary energy use and $\mathrm{CO}_{2}$ emissions. Investors and contractors must make individual decisions, based on the specific situation at a given site. However, a preliminary process of strategic location identification and selection can be helpful in coordinating such investments and construction projects. The approach outlined here is intended as an aid to decision-making, and the identification of sites, which can, from a technical point of view, be easily developed. It also aims to be an introduction to the subject for decision makers at a community and corporate level (e.g. city planners and network operators), and to offer a first, but by no means complete, overview. Taking the city of Oldenburg, Germany as an example, a model to aid decision-making was developed and tested. This was done within the scope of the German-Dutch Interreg Project 'denewa'.
\end{abstract}

\section{Project Framework}

At the beginning of the 90s the European Union launched the INTERREG initiative with the intention of narrowing the gap in the levels of development between the European regions, and strengthening economic cohesion. INTERREG IVA aims to further cross-border cooperation, focusing on the free exchange of knowledge. At the same time, action to encourage market growth should be taken. The results presented here are taken from the project "denewa - Deutsch-Nederlanske Wassertechnologie" (denewa - German-Dutch Water Technology).

The OOWV (Oldenburg and East-Frisian Water Board) and the iro GmbH Oldenburg (Institute of Pipe Engineering) concentrated on developing a concept and a model for decision making. Their part of the project is called "Heat from wastewater". The project was presented to the environment committee of Oldenburg city council. As a result the council decided to support the project - an important endorsement. The Institute Wetsus at the University of Leeuwarden in the Netherlands is the lead-partner of the project (www. denewa.eu). 


\section{Theoretical Potential for Oldenburg}

A good starting point is to calculate the theoretical energy potential as a point of reference. For city-wide planning purposes, this potential can be referred to in order to make initial, non-specific estimates of the available capacity. The specific useable heat energy in wastewater, given a cooling factor of $2 \mathrm{~K}$, is $2.3 \mathrm{kWh} / \mathrm{m}^{3}$ (BÖGE \& KNIES 2013). The Oldenburg wastewater treatment plant handles an average of between 30,000 and $33,000 \mathrm{~m}^{3}$ of wastewater per day (ib.). To be on the safe side, the lower figure is taken, providing a flow rate of $1,250 \mathrm{~m}^{3} / \mathrm{h}$. Thus, the theoretical heat energy potential of the wastewater of Oldenburg is $1,250 \mathrm{~m}^{3} / \mathrm{h}$ (wastewater and combined wastewater) $* 2.3 \mathrm{kWh} / \mathrm{m}^{3}=2,875 \mathrm{~kW}$.

This figure is a rough indication of the theoretically achievable output in Oldenburg's wastewater system. The technically feasible potential is subject to other factors such as, for example, geothermal influence, which can heat up the water, or the location of feed pipes with heat energy, which can offset the cooling process. In addition, it is important to take into account the effect of dry weather spells, particularly if they occur in the winter heating period.

The impact on wastewater treatment itself should also be taken into account, although, according to HAMANN (2014, p. 83), an overall $2 \mathrm{~K}$ cooling of the wastewater supply is the exception rather than the rule.

\section{$3 \quad$ Assessment of Specific Potential}

The theoretical potential merely expresses that it is worth considering the extraction of heat energy from wastewater. To make the exploitation of this energy source feasible, it is first necessary to determine the existing conditions, to allow further decisions to be made. These include spatial, energy-related, technical, and organizational conditions, which will be specified hereafter.

\subsection{Assessment of Specific Spatial Potential}

For any specific target area it is possible to gather information and data from a wide variety of sources, disciplines, and authorities, and compare it within a given framework.

The cadastral sewer map of the OOWV (Oldenburg and East-Frisian Water Board) and the land registry maps, as well as data from local community land registries were used as the basis for all further work.

Starting position: Sections of sewer with a reliable and sufficient wastewater flow rate should be in close proximity to property and planned property development, which have a given minimum basic energy requirement.

Proceeding in this manner, it is possible to exclude from the outset sewers, which are too small, detached family houses, and isolated locations.

The minimum basic energy requirement should be over 100kW (DWA 2009). More recent estimates put the figure for a commercial facility at $300 \mathrm{~kW}$ (STODTMEISTER 2013). Given 
the current attention being paid to building insulation and improving energy efficiency for technical building services, these are not insignificant figures.

As it was only possible to determine the wastewater volume for a specific location on request, a nominal width was used in the hydraulic models to determine a classification. This should not be seen as bypassing technical solutions, but simply as a way of pre-selecting sections of sewer pipe with a - potentially - sufficient flow of wastewater. The approach outlined here was necessary as the hydraulic information is currently only available on request. In future, pre-selection based on the nominal width will not be necessary, as it will be possible to make direct use of hydraulic calculations of the dry-weather flow rate. Thus, in the future, the nominal width will only be of marginal interest as a selection criterion. In local communities, where mainly dirty water (not combined) pipes are in use, it may be economical to exploit the energy from smaller diameter pipes (FIW 2013).

Pressurized pipes have been excluded from this study as the interruptions in pumping mean that the flow is not constant. In larger cities, the pressurized pipe systems are better suited, as shown by the example of the IKEA site in Berlin (SCHITKOWSKY 2010).

Pumping stations with large storage basins also have the potential to be used for the extraction of energy from wastewater. To this end, only pumping stations in Oldenburg which process at least $700,000 \mathrm{~m}^{3}$ of wastewater annually were considered. This applies to six pumping stations, which were all assigned a $120 \mathrm{~m}$ buffer zone. The buffer zones were all checked in regard to the situation of the building itself, and the catchment area to which it is connected. The results show that only the immediate vicinity of one pumping station is worthy of consideration, as shown below as test area nr. 4.

The aim of the study is to enable decision makers at a community and corporate level (e.g. city planners and network operators) to strategically plan the development of wastewater heat recovery units (Table 2) with reference to three levels of priority (see Table 1):

Table 1: Priority levels

\begin{tabular}{|l|l|}
\hline Priority level & Description \\
\hline Priority A & $\begin{array}{l}\text { Locations/areas which are highly likely to be suitable, given the sewer and } \\
\text { property situation. }\end{array}$ \\
\hline Priority B & $\begin{array}{l}\text { Locations/areas which are in close proximity to sewer sections of significant } \\
\text { interest. }\end{array}$ \\
\hline Priority C & Locations/areas whose suitability has to be assessed separately. \\
\hline
\end{tabular}


Table 2: Assessment of specific spatial potential - process steps

\begin{tabular}{|c|c|}
\hline Process & Criteria/Actions \\
\hline $\begin{array}{l}\text { Selection of pipe } \\
\text { sections }\end{array}$ & $\begin{array}{l}\text { Selection of pipes with nominal width } \\
<600 \mathrm{~mm} \\
\text { (combined wastewater/sewage) }\end{array}$ \\
\hline & $\begin{array}{l}\text { Selection of pipe sections with nominal width } \\
\geq 600 \mathrm{~mm} \text { (combined wastewater/sewage) }\end{array}$ \\
\hline $\begin{array}{l}\text { Analysis of sur- } \\
\text { roundings }\end{array}$ & $\begin{array}{l}30,90 \text {, and } 120 \mathrm{~m} \text { buffer zones along the pre- } \\
\text { selected pipe sections. In individual cases the } \\
\text { buffer zones were reduced along "natural" }\end{array}$ \\
\hline$\sqrt{2}$ & as per cadaster map and aerial photos etc.) \\
\hline $\begin{array}{l}\text { Potential energy } \\
\text { consumers }\end{array}$ & $\begin{array}{l}\text { Overlap of the buffer zones and properties on } \\
\text { the land registry map. }\end{array}$ \\
\hline$V$ & $\begin{array}{l}\text { The result is a spatial overview of property in } \\
\text { the immediate proximity of pipe sections } \\
\text { with useable potential. The buffer zones } \\
\text { permit a first assessment of the costs and the } \\
\text { complexity of development. }\end{array}$ \\
\hline
\end{tabular}

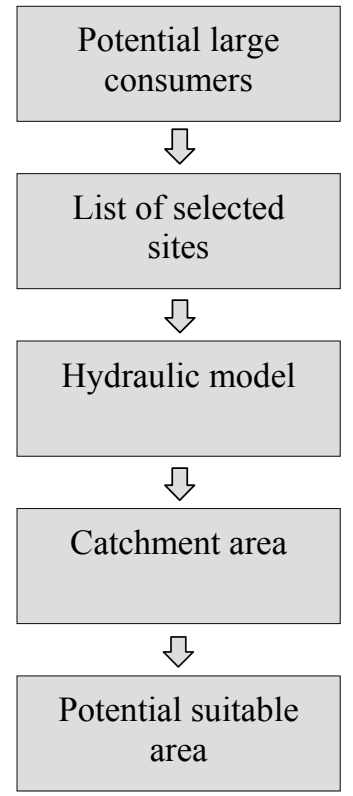

Pre-selection of large and/or connected building complexes and/or planned developments within the buffer zone.

Listing of pipe sections, which could supply potential large consumers with heat energy.

Testing the hydraulic model on a dry-weather sewer with sufficient flow rate $(>101 / \mathrm{s})$

Assessment of the catchment area with respect to input situation (housing re-structuring, commercial area developments, etc.).

Definition of potentially suitable area with connected building complexes.

\section{Priority B}

Categorization

Priority C

(1) 
Figure 1 gives an overview of priority A areas.

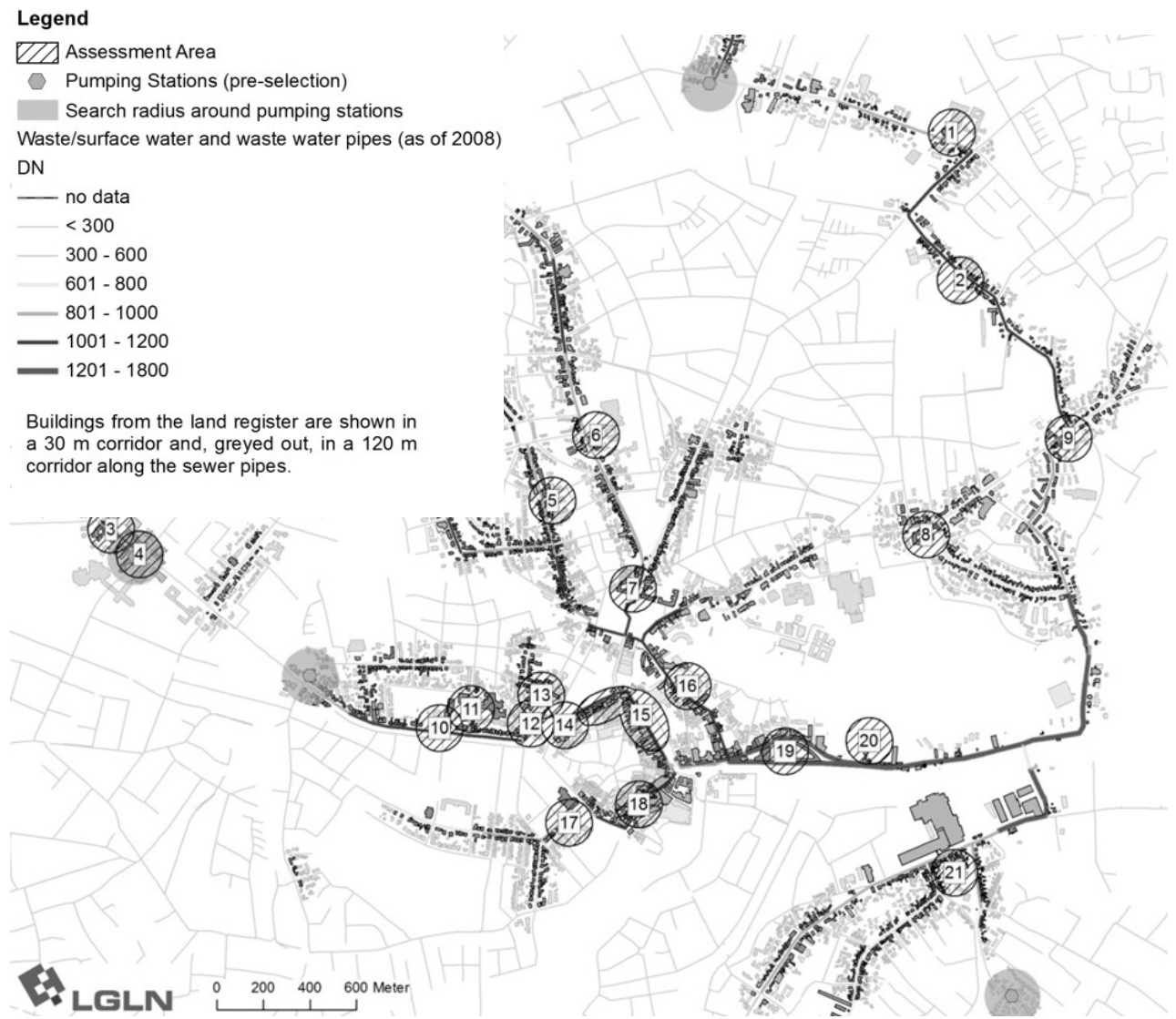

Fig. 1: Cartographic overview of the priority A areas

\subsection{Assessment of Specific Energy Potential}

Assessing the spatial potential is the first step towards matching energy availability and energy requirements. The next step is to establish to what extent the available energy potential matches up with energy requirements. To this end the hydraulic model is used to calculate a theoretical heat energy potential in order to compare this with the energy requirements of the building or building complex in question. The city of Oldenburg provided data on the energy consumption of communal facilities for the project.

The example of location 1 in Figure 1 (Comprehensive School, IGS Flötenteich, Hochheider Weg) will be used to illustrate the matching process.

The adjacent pipe is a sewerage pipe with an egg-shaped profile and a nominal width of $900 / 600$. According to the hydraulic model, the dry-weather flow-rate Q is $37 \mathrm{l} / \mathrm{s}$, and the temperature loss is assumed to be $\Delta \mathrm{T} 2$ Kelvin. 
The theoretical heat energy potential is $306.36 \mathrm{~kW}$ :

$$
\begin{gathered}
1 \mathrm{l} / \mathrm{s}=3.6 \mathrm{~m}^{3} / \mathrm{h} \rightarrow \quad 37 \mathrm{l} / \mathrm{s}=13.2 \mathrm{~m}^{3} / \mathrm{h} \\
133.2 \mathrm{~m}^{3} / \mathrm{h} \cdot 2.3 \mathrm{kWh} / \mathrm{m}^{3}=306.36 \mathrm{~kW}
\end{gathered}
$$

Assuming the use of a heat pump with an annual performance of 4 (JAZ), the following overall heat output can be calculated:

$$
306.36 \mathrm{~kW} \cdot 4 /(4-1)=408,48 \mathrm{~kW}
$$

For this particular site, an annual energy consumption of $1,448,027 \mathrm{kWh}$ was calculated after weighting for local weather conditions. To calculate the required energy value, the heating load of the building is estimated, based on available energy use figures and using the following formula from page 2 (VDI 1993) of VDI 2067 (German Engineers Association):

$$
\mathrm{QN}, \mathrm{Geb}=\mathrm{QHA} /((\mathrm{fV} \cdot \mathrm{bVH}))
$$

$\mathrm{QN}, \mathrm{Geb} \rightarrow$ Norm - heating load of building $(\mathrm{kW})=/(\mathrm{x})$

$\mathrm{QHA} \rightarrow$ Annual heating energy use (kWh/a)

$\mathrm{fV} \rightarrow$ Conversion factor (locations outside Düsseldorf, for Oldenburg: 1047)

$\mathrm{bVH} \rightarrow$ Hours of full-use (based on Düsseldorf)

The hours of full-use are estimated based on VDI (1993). Due to the fact that the school has an additional administration block and a sports hall, the factor "School, in use for multiple shifts" was set at 1300. This figure is then multiplied by the conversion factor for Oldenburg.

This results in an estimated heating load of $(1,448,027 \mathrm{kWh} / \mathrm{a}) /((1.047 \cdot 1300 \mathrm{~h} / \mathrm{a})) \approx$ $1064 \mathrm{~kW}$.

Finally, a so-called Sankey-Diagramme can be used to illustrate if and how the theoretical energy potential and the required energy match up.

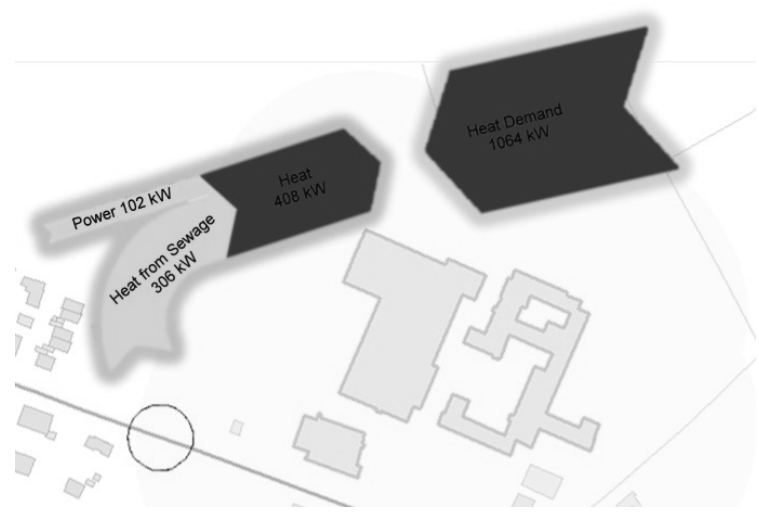

Fig. 2:

Site analysis IGS School Flötenteich

This simple comparison clearly shows that the potential energy available does not nearly cover the energy requirement. Given this, it would make sense to discuss a system, which 
covers the basic energy requirements. This would require detailed information about energy use levels in real time for the buildings in question.

\subsection{Verification by Measurement}

The steps so far have served to match up promising sewer sections and suitable energy consumers. For the purposes of realistic planning, however, these rough estimates of energy potential must be put to the test by carrying out detailed measurements in the pipes themselves.

In the course of the project, and associated preliminary work, enquiries were received from investors and the city of Oldenburg on the basis of the cartographic overview, and measurements were carried out on specific pipe sections. These in-situ measurements allow a much more accurate evaluation of the potential to be made. At the same time, the results from the hydraulic model in the combined water sewers could be checked (table 3):

Table 3: Listing of the potentially suitable areas and pipe sections based on Figure 1

\begin{tabular}{|r|l|l|l|l|l|l|}
\hline No. & Description & Diameter & $\begin{array}{l}\text { l/s } \\
\text { Model }\end{array}$ & $\begin{array}{l}\text { l/s } \\
\text { avg. } \\
\text { max. } \\
\text { min. }\end{array}$ & $\begin{array}{l}\text { Temp. } \\
\text { avg. } \\
\text { max. } \\
\text { min. }\end{array}$ & Period \\
\hline $\mathbf{1}$ & IGS Flötenteich & $\begin{array}{l}\text { (egg-shape) } \\
\text { School }\end{array}$ & 37 & 72.0 & 17.1 & $28.09 .2011-$ \\
& & & 179.1 & 18.8 & 4.10 .2011 \\
\hline \multirow{6}{*}{} & OZ Alexanderstr. & 1000 & 19 & 27.9 & 10.8 & $24.02 .2014-$ \\
& & & 68.8 & 14.2 & 03.03 .2014 \\
\hline $\mathbf{1 0}$ & Jade University of & 1200 & 253 & 288.2 & 16.4 & $12.10 .2011-$ \\
& Applied Sciences & & & 343.2 & 17.8 & 17.10 .2011 \\
\hline $\mathbf{2 0}$ & Harbour develop- & 1500 & 506 & 374.6 & 12.8 & $26.04 .2012-$ \\
& ment area & & & 503.1 & 13.4 & 28.04 .2012 \\
& & & 211.1 & 11.9 & \\
\hline
\end{tabular}

The measurement results present a very consistent picture:

Location 1 showed very high fluctuations and the average is well over the estimates from the hydraulic model. These fluctuations were caused by the operation of higher level pumping stations, amongst other influences. The temperatures are only of limited significance, as the measurements were carried out in autumn, and, thus, do not reflect the situation in winter. It must, however, be considered that this is only a sewer pipe (not combined), and greatly reduced temperatures are not to be expected.

At location 6, a higher rate of flow was also measured in the combined water pipe. The temperatures measured give a good reflection of the situation in the heating period. The temperature level is just about high enough for heat recovery from wastewater. The heat exchanger would have to be of an appropriate size or the heating unit could be adapted (e.g. a combination fuel system to cover the base load). 
At location 10, the hydraulic model estimate for the combined water pipe approximates quite closely to the measurements. As the measurements were carried out in autumn, the temperatures are of limited significance. The pilot project unit at iro, which is in the immediate vicinity has been monitored since October 2011. In March 2013 an average temperature of 8 degrees Celsius was measured, due to the high volume of melt-water (BÖGE 2014).

At location 20, the volume of combined water was significantly lower than predicted by the hydraulic model. Here too, the spring temperatures are only of limited use. In February 2013 regular measurements were carried out, giving an average temperature of 9 degrees Celsius. These results underline the fact that energy recovery will be subject to short-term fluctuations, in a hard winter with increased levels of melt-water.

This can be compensated for by the installation of combination fuel heating systems, or by using a different sized heat exchanger in combination with regular and consistent programming of the heating system.

\section{Efficiency Through Coordination}

The efficient use of heat energy from wastewater depends on many peripheral factors. The theoretical and measured potential of any one site is no guarantee of reliable and economic operation.

In 2013, as part of the denewa project, workshops were held with users, planners, and manufacturers to examine critical aspects, which are essential to the successful implementtation of a project. Surprisingly, the conclusion was reached that the technical aspects were not considered to be of prime importance. On the contrary, communication and coordination on several levels and between different technical services providers (heat exchanger, heat pump, technical building services) were thought to be of greater importance. The essential points are presented in the following sections.

\subsection{Coordination of Pipe-related Installations}

The installation of various types of heat exchanger systems (by-pass systems, channel heat exchangers, etc.), requires an existing pipe to be worked on and adapted. If these works are correctly coordinated the costs can be kept to a minimum, boosting the economic efficiency of the unit as a whole.

If the heat exchanger is pre-installed in the pipe section, the synergy is obvious. The installation of such pipe sections can be included in the planning of new heat recovery projects.

\subsection{Coordination of the Planning Process}

The following points were considered to be of particular importance:

- Transparent decision-making and information regarding base load cover and rating of specific units and facilities.

- Improved transparency regarding all details of units. 
- Improved communication between technical service providers.

- Training/qualifications.

- Appropriate style of communication for different target groups (local authorities/industry).

- $\quad$ Risk reduction for users.

- Continual updating of rules/standards and definition of interdependent operational interfaces.

- Initial consultations should be product-neutral, e.g. by independent local energy advisors.

The essence of the workshop is that any solutions must be appropriate to the specific circumstances and involve all the service providers.

\subsection{Coordination of Installation and Operation}

The following points were considered to be of particular importance:

- Qualification of building site managers/building site supervisors.

- Development of new heating supply concepts (Keyword: cold local heating networks).

- Distant diagnosis and maintenance and clear differentiation of faults when reported (remediation of simple faults), simple fault-diagnosis for users.

- Coordination and timing of pipe cleaning before the winter heating period to increase the thermal conductivity of by-pass heat exchangers, see also (BÖGE 2014).

The essence of the workshop is that manufacturers are showing a new understanding of their clients' needs, and now offer integrated, complete systems. Moreover, operation in untried areas of application was discussed: frost-free operation of bridges, city squares and railway points, new target groups (greenhouses), cooling units etc.

Further documentation is available on the Internet site: http://energie-im-abwasser.de

\section{Outlook}

The results of the workshops are not commandments set in stone, but rather a call to action for the future. The situation is comparable to that in the wind energy sector about 25 years ago. Following an initial phase of gathering practical experience, there must be a standardization of components and interfaces to existing systems and units so that, in the longterm, the technology can gain acceptance. Initially, it is important to develop sites and locations with a high potential for heat recovery, so that the steep learning curve is seen as rewarding. A poignant comparison: The first wind turbines were not built in the mountains.

A challenge coming over the horizon is, alongside heat recovery, the use of wastewater for cooling. Wastewater is an ideal medium to transport large quantities of excess energy away 
from overheated city centres. Here too, it is naturally essential that wastewater purification must not be jeopardized.

In this respect it would be helpful in future to expand the concept and more closely define the areas of application for the thermal exploitation of wastewater. This would be of use in the strategic development of economically viable sites and connection points. This definetion would also, when taken to its logical conclusion, include not only the recovery of heat energy from wastewater, but also cooling applications and the retrieval of gas from water treatment facilities, which could be used to generate electricity.

In Oldenburg, two bigger projects are planned in 2015 supplying a total of $15.500 \mathrm{~m}^{2}$ of floor area in a first step, with the option of expanding by $11.000 \mathrm{~m}^{2}$ in the next step.

\section{References}

BÖGE, M. (2014), Betriebserfahrungen - Abwasserwärmenutzung in Oldenburg, Vortrag auf dem Rohrleitungsforum 2014, Oldenburg. .http://www.energie-im-abwasser.de/ ContentFiles/News/Documents/File1 7.pdf?id=715619614 (16.06.2014)

BöGE, M. \& KNIES, J. (2013), Faktoren für eine erfolgreiche Nutzung von Wärme aus Abwasser. In: KA - Korrespondenz Abwasser, Abfall, 10, 10-19.

DWA (2009), DWA-Regelwerk - Merkblatt DWA-M 114. Energie aus Abwasser - Wärme - und Lageenergie. Hennef.

FIW - FORSCHUNGSINSTITUT FÜR WASSER- UND ABFALLWIRTSCHAFT AN DER RWTH AACHEN E. V (2013), Potenziale und technische Optimierung der Abwasserwärmenutzung. Kurzbericht.

http://www.lanuv.nrw.de/wasser/abwasser/forschung/pdf/Kurzbericht\%20Abwasserwae rme_Nov_2013.pdf (04.07.2014)

HAMANN, A. (2014), Einfluss der Wärmeenergieversorgung aus öffentlichem Abwasser auf die Abwasserreinigung. 3R, Fachzeitschrift für sichere und effiziente Rohrleitungssysteme, 03/2014, 80-83. Vulkan Verlag. ISSN 2191-9798.

SchitKowsKy, A. (2010), Wärmerückgewinnung aus Abwasser (Vortrag). Berliner Wasserbetriebe. http://www.abwasserbilanz.de/downloads/2010/101213_schitkowsky.pdf (17.06.2014).

StodTMEISTER, W. (2013), Abwasser ist eine lukrative Wärmequelle. Diese Energie wird von Kommunen immer häufiger genutzt. Business Geomatics. http://www.businessgeomatics.com/download/pdf/BG-2-13.pdf (16.06.2014)

VDI - Verein Deutscher Ingenieure (1993), VDI-Richtlinien - VDI 2067 Blatt 2. Berechnung der Kosten von Wärmeversorgungsanlagen Raumheizung. (Beuth) Berlin. 